\title{
REBUILDING BRIDGES: THE BAR, THE BENCH, AND THE ACADEMY"
}

\author{
SETH P. WAXMAN ${ }^{\dagger}$
}

It's an honor to be here on this momentous occasion-the 150th anniversary of the founding of Penn's Law Review. I understand that Penn is engaged in a bitter struggle with Harvard for the title of the "oldest law review." Since it appears that you can truly claim 150 years, you seem to be the victor. As the oldest law review, however, you have a lot to answer for. And so, on this great occasion, I would like to reflect for a few minutes about some of the problems with law reviews, and more broadly with law schools and the legal profession, and then offer a few suggestions about how things perhaps could be made better.

More than sixty years ago, in an essay that has become deservedly famous, a young, dynamic law professor said goodbye to law reviews. Vowing never to write another law review article, Fred Rodell said: "There are two things wrong with almost all legal writing. One is its style. The other is its content. That, I think, about covers the ground." That does sum it up nicely. But Rodell went on from there. He pointed out that

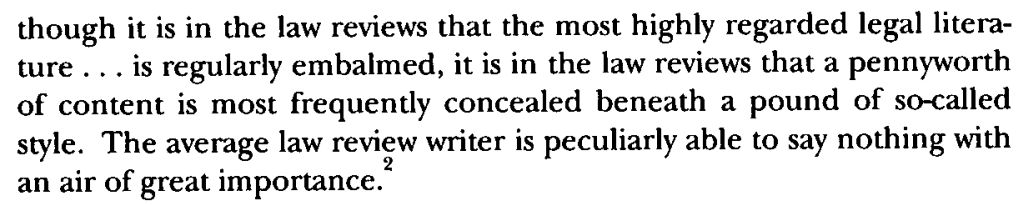

Rodell complained that law review articles weren't clear, weren't funny, and weren't interesting. "It seems to be a cardinal principle of

- Delivered as the keynote address at the University of Pennsyluania Law Review's Sesquicentennial Anniversary Banquet, April 5, 2002.

${ }^{t}$ Partner, Wilmer, Cutler \& Pickering, and Distinguished Visitor from Practice, Georgetown University Law Center. From 1997 until 2001, Mr. Waxman served as Solicitor General of the United States. He gratefully acknowledges the assistance of Danielle Spinelli.

1 Fred Rodell, Goodbye to Law Reviews, 23 VA. L. REV. 38, 38 (1936). Rodell was twenty-nine when the essay was published. See G. Beth Packert, Note, The Relentless Realist: Fred Rodell's Life and Writings, 1984 U. ILL. L. REV. 823, $824 \mathrm{n.7}$ (reporting that Rodell was born March 1, 1907).

${ }^{2}$ Rodell, supra note 1 , at 38 . 
law review writing and editing," he observed, "that nothing may be said forcefully and nothing may be said amusingly. ... The best way to get a laugh out of a law review is to take a couple of drinks and then read an article, any article, aloud. That can be really funny." jected to the law reviews' infatuation with the footnote-a "foible," he said, that "breeds nothing but sloppy thinking, clumsy writing, and bad eyes." rious point was that legal writing, by and large, was irrelevant "navelgaz[ing]." He saw the typical law review article as "the building up, rebuilding, and sporadic knocking down of pretty houses of theory foundationed in sand and false assumptions. ${ }^{.6}$ And he said:

With law as the only alternative to force as a means of solving the myriad problems of the world, it seems to me that the articulate among the clan of lawyers might, in their writings, be more pointedly aware of those problems, might recognize that the use of law to help toward their solution is the only excuse for the law's existence, instead of blithely continuing to make mountain after mountain out of tiresome technical molehills. $^{\text {? }}$

I'll leave it to you to decide whether Rodell's picture of law reviews is outdated or not. I first came across Rodell's article when I was editing a review of another publication for which you are partly responsible-the twelfth edition of A Uniform System of Citation, affectionately referred to as the Bluebook. ${ }^{8}$ (For those of you who have been living in a cave for the past few years-or in the real world-we're now up to the seventeenth edition.) But back in the days of the twelfth, Rodell's essay struck me as depressingly accurate. In particular, I was struck by the notion that law review literature-and much of the work done in law schools-largely described a closed universe, with little or no input from, or effect on, the outside world.

Since leaving law school, I've continued to ponder what can be done about this phenomenon. Why does there often seem to be so little connection between the work being done in law schools and published in law reviews and the profession for which law schools pre-

${ }^{3}$ Id. at $38-40$.

${ }^{4}$ Id. at 41.

${ }^{5} I d$. at 43.

${ }^{6} \mathrm{Id}$. at 42.

${ }^{7}$ Id. at 43.

${ }^{8}$ See W. Duane Benton, Developments in the Law-Legal Citation, 86 YALE L.J. 197 (1976) (reviewing THE BLUEBOOK: A UNIFORM SYSTEM OF CITATION (Columbia Law Review Ass'n et al. eds., 12th ed. 1976)). 
pare their students? Why does the relationship among law schools, judges, and practicing lawyers seem so dysfunctional?

My tenure as Solicitor General (SG) gave me a unique opportunity to look at this dynamic from a unique perspective. The legal profession is composed of three branches-the academy, the bench, and the bar-which increasingly seem to define separate worlds. Traditionally, the SG seeks to reach out to all three worlds. As the United States' lawyer in the Supreme Court and the nation's chief litigation strategist, the SG is, of course, first and foremost a practicing lawyer. But, as the so-called "Tenth Justice," the SG also has extensive and important responsibilities to, and contact with, the judiciary. And the position claims a scholarly pedigree as well: the SG is the only officer of the United States required by statute to be "learned in the law." Moreover, perhaps because in recent decades so many SGs have come from the academy, by tradition SGs tend to involve themselves with the academy by publishing, lecturing, and participating in academic conferences.

Since leaving government, I have tried to continue to straddle the gap between private practice and academia by combining law-firm practice with teaching and lecturing at universities-delivering what practitioners would consider serious academic lectures, but what the academy unquestionably views as "scholarship lite." For me, at least, trying to maintain a presence in both worlds is very hard work. I do it because I find it deeply rewarding to expose myself to the best of both. And of course I live in the hope (perhaps delusional) that students and faculty find it rewarding to hear practicing lawyers speak about developments in legal doctrine. But I am an oddity: the reality is that few people in legal practice, public or private, are able to maintain active involvement in the academy.

It didn't used to be that way. For much of this nation's history, the bench, the bar, and the academy were highly integrated with each other. Judges and lawyers were also teachers, and the bonds between the legal academy and the rest of the profession were varied and vital. Over time, though, this kind of exercise in well-roundedness has become considerably more challenging because the realms of practice and the academy have drifted farther and farther apart.

Let me use law reviews as a proxy for the legal academy in general. Many of the things Rodell observed that made the law reviews seem isolated and irrelevant have only been magnified. Footnotes are one

\footnotetext{
${ }^{9}$ Act of June 22, 1870, ch. 150, § 2, 16 Stat. 162, 162.
} 
barometer. Though perhaps an annoyance in Rodell's time, they have since multiplied out of all control. One article in the 1980s, which, at least for a time, held the title of most-footnoted law review article, required the reader to look at the bottom of the page nearly 5000 times (4824, to be precise). ${ }^{10}$ Noel Coward is supposed to have said that reading footnotes "is like going downstairs to answer the doorbell while making love." 4824 is a lot of trips downstairs.

What about Rodell's objections to content? Indeed, the content of law reviews has changed since Rodell's time. Rodell's tongue-incheek examples of typical law review topics were "The Rule Against Perpetuities in Saskatchewan" and "Some New Uses of the Trust Device to Avoid Taxation."' I'm sure you'll agree that titles like those are very unlikely to show up on your cover today.

When Penn's law review was founded in 1852 as the American Law Register, it was "published, written and edited by practicing lawyers for practicing lawyers." ${ }^{18}$ In 1895 , one of the editors was named dean of the law school. ${ }^{14}$ He had the school take over publication and handed control over to a board of student editors-a major turning point. ${ }^{15}$ Even so, the Review continued to be focused on service to practitioners. In 1923, the editorial board stated that it hoped to form a closer relationship with "'practicing attorneys and judges[,] so that more of the latter [could] become contributors [and] the Law Review [would] be in a position to render to the legal profession a service second to that of no other law school publication."'16 The Harvard Law Review's original goals were similar. In its first issue, the editors said: "Our ob-

${ }^{10}$ The article in question is Arnold S. Jacobs, An Analysis of Section 16 of the Securities Exchange Act of 1934, 32 N.Y.L. SCH. L. REV. 209 (1987). It is cited as the article with the most footnotes in Kenneth Lasson, Scholarship Amok: Excesses in the Pursuit of Truth and Tenure, 103 HARV. L. REV. 926, 937-38 (1990).

$"$ Lasson, supra note 10, at 940 (quoting Paul M. Barrett, To Read This Story in Full Don't Forget to See the Footnotes, WALl ST. J., May 10, 1988, at A1). I say "supposed" because, though the statement is often attributed to Coward, this attribution may not be entirely correct. See Arthur Austin, Footnote Skullduggery and Other Bad Habits, 44 U. MiAMI L. Rev. 1009, 1012 n.20 (1990) (noting the difficulty of tracing the statement back to its source).

${ }_{12}^{12}$ Rodell, supra note 1, at $42-43$.

${ }^{13}$ Edwin J. Greenlee, The University of Pennsylvania Law Review: 150 Years of History, 150 U. PA. L. REV. 1875, 1880 (2002).

${ }^{14}$ Id.

${ }^{15} \mathrm{Id}$.

${ }^{16} I d$. at 1882 (second and fourth alterations in original) (quoting Derek Davis, "A Living Science and a Present Art": A History of the University of Pennsylvania Law School 188-89 (2000) (unpublished manuscript, on file with the University of Pennsylvania Law School)). 
ject, primarily, is to set forth the work done in the school with which we are connected .... Yet we are not without hopes that the Review may be serviceable to the profession at large."

I venture to say that no law review today sees its purpose as rendering service to "the profession at large"-or if it does, it is seriously delusional. The ties between the law reviews and practicing lawyers and judges are much weaker than they once were. Empirical studies have substantiated what practitioners and judges intuitively know: One recent study found that judges' citations to legal scholarship in their opinions had declined by almost fifty percent over the last twenty years, with the decline accelerating over the last ten years. ${ }^{18}$ Even at the Supreme Court, academic citations are viewed as largely irrelevant-only a true naif would blunder to mention one at oral argument. The decline of doctrinal scholarship-at least as a route to tenure at top law schools-may be one reason that law reviews are less useful to judges and practitioners today than they were in the past.

Law reviews, of course, reflect the institutions they serve. Many prominent lawyers, judges, and scholars have lamented what Judge Harry Edwards called "the growing disjunction between legal education and the legal profession." 19 The causes of this disjunction are surely too complex to explore fully here. One thing, though, is clear: Each branch of the profession has changed substantially over the past few decades, and each bears responsibility for the resulting fragmentation.

Consider first the change in law schools. As professional academies, law schools have traditionally gazed, Janus-like, at two different worlds-the world of the research university and the world of legal practice. Increasingly, though, in recent years many of the country's elite law schools have become transfixed on the former at the expense of the latter. Increasingly, law professors see themselves more as colleagues of sociologists, economists, and philosophers than of judges and lawyers. Publishing is now more important, both for landing a teaching job and for advancing professionally, than ever before.

As a consequence, it has become increasingly difficult for people

\footnotetext{
${ }^{17}$ Notes, 1 HaRV. L. REV. 35, 35 (1887).

${ }^{18}$ Michael D. McClintock, The Declining Use of Legal Scholarship by Courts: An Empirical Study, 51 OKLA. L. REV. 659, 660 (1998).

${ }_{19}$ Harry T. Edwards, The Growing Disjunction Between Legal Education and the Legal Profession, 91 MICH. L. REV. 34, 34 (1992); see also Symposium, Legal Education, 91 MICH. L. REV. 1921 (1993) (publishing eighteen articles addressing Judge Edwards' original criticism).
} 
with significant amounts of experience as practicing attorneys to be hired as law professors. Sadly, the emphasis of most top law schools on publication over teaching ability or practice experience means that many supremely talented law teachers never even try to join, or to interact with, the academy. And their perspectives and wisdom are consequently lost, both to students and professors.

I'm not advocating a return to the days of "The Rule Against Perpetuities in Saskatchewan." Indeed, many of the changes in the law schools have been good ones. The advent of interdisciplinary scholarship, for instance, has been refreshing, and the best of this scholarship has profoundly impacted both lawyering and judging. The growing presence of women and minorities on law school faculties, which has enhanced the variety of both theoretical and doctrinal scholarship, has been an unqualified change for the better. And at its best, theoretical scholarship is invigorating for those privileged to enjoy it.

The problem, in my view, is one of degree. The law schools' tilt toward pure scholarship, and especially theoretical scholarship, has often come at the expense of other things they can and should do. It's the lack of balance that is disheartening-the fact that the pursuit of scholarship has too often intensified the increasing separation of the academy from the rest of the legal world.

That doesn't have to be the case. Take medical schools, for example. Many, if not most, members of medical faculties are also practicing physicians, and their research, teaching, and clinical practices all benefit because they are not pursued in isolation from one another. There is certainly room for law schools to move in that direction.

Of course, the practice of law has changed as well, and in ways that have moved practicing lawyers farther away in spirit from the law schools and the judiciary. More and more, law firms have come to resemble businesses, and many lawyers may now feel that they have more in common with their business clients than with their colleagues in the other two branches of the legal profession. As others have said, if the law schools' motto is "publish or perish," the implicit motto adopted by many law firms is "bill or be banished." "This narrow view of a noble profession, combined with the extreme time pressures of modern practice, can render sustained reflection on social, theoretical, or interdisciplinary concerns a costly luxury.

What about judges? With law professors focused on their fellow

${ }^{20}$ Edwards, supra note 19 , at 67. 
scholars and practitioners intent on the bottom line, judges have themselves retreated into their own increasingly hermetic world. Dockets have grown, cases have become more complex, and most judges consequently find less time for reflection, writing, or teaching. Meanwhile, increasingly stringent ethical proscriptions have made interactions between judges and practitioners-even casual interactions unrelated to cases-less common and less comfortable.

So how do we make things better? Certainly it is not by excoriating each branch for striving for excellence in its own unique mission. Rather, the solution, it seems to me, lies in finding ways to rebuild bridges among the three branches. So I'll end with a few modest suggestions. Given the setting, I'll focus on the academy.

What we really need are far more venues in which practitioners, scholars, and judges can talk to one another. I don't exclusively mean physical places. I mean forums in which members of all three branches can engage, together, in public discourse about the law. Of the three branches, law schools are far and away the best suited to provide most of these forums. There are many ways law schools could improve the dismal status quo.

For one thing, law schools can and should provide more opportunities for accomplished practitioners to visit, lecture, and engage in dialogue on important substantive issues. Annually, for example, the Indiana Supreme Court sponsors an endowed lecture at each law school in the state. The tradition is to bring an eminent practitioner to the university to give a serious, substantive lecture, accompanied by events in which practitioners, judges, and law professors and students come together to think and talk about issues affecting them all. The University of Virginia annually awards a "medal in law" to a distinguished judge or lawyer, who is expected (on the occasion of the medal) to spend a few days at the university teaching, lecturing, and interacting with both students and faculty. Programs like these greatly enrich the quality of inquiry and discourse about the law.

Second, law schools can provide print forums-either in the law reviews themselves or in other publications-in which professors, practitioners, jurists, and students can write about the law in a way that is more inviting and accessible to the profession as a whole than most current legal scholarship. The Yale Law School, for example, has sponsored a new magazine, Legal Affairs, which has serious, beautifully written, and invitingly displayed articles on current legal issues. One look at the cover of Legal Affairs reveals that it is aimed at a far broader audience than are traditional law reviews. As another example, the 
recently resurrected Green Bag publishes shorter and less traditional legal writing by scholars, practitioners, and judges. In the editors' words, it's a "place ... to toss out a creative thought, or make an argument that merits more than a letter to the editor but fewer than fifty footnotes." ${ }^{21}$

Publications like these fill a profound need, for there is an immense field of play between the traditional fare of law reviews on the one hand and magazines like the American Lawyer on the other. There is no good reason why law reviews can't reclaim some of that territory for themselves. Surely the journal that twenty-five years ago published an essay on The Common Law Origins of the Infield Fly Rule can rise to this challenge.

Let me make one final point. Premier law schools like Penn need to make affirmative efforts to hire gifted people who have been successful in practice, public and private. I'm referring not just to adjunct professors who rush in and out. I'm referring not simply to the need for more clinical faculty. I'm also talking about practitionerscholars who are fully integrated into the academic faculty.

Reflecting on my own experience in law school, I think most about Burke Marshall, who came to Yale after practicing at a Washington law firm and working in the Kennedy administration. Professor Marshall didn't put his feet up and tell war stories: he produced some of the most insightful scholarship in the institution and engaged law students in a way few of his colleagues could match. His years in practice and government brought a refreshing dimension to academic debate. Finding and claiming the next generation of Burke Marshalls should be a priority of every elite law school-not just for the sake of the students, but also, importantly, for the faculty.

All of us in the broad circle of the legal profession should endeavor to take one large step toward the center-toward a place where we can speak with each other without shouting; toward an environment in which each of us, pursuing excellence in his or her own discipline, can enrich the understanding of colleagues in other disciplines within the endeavor of law.

And in trying to be better, let's not let the perfect become the enemy of the good. Remember Professor Rodell's vow never again to

${ }^{21}$ A Short Profile, THE GREEN BAG, at http://www.greenbag.org (last modified Mar. 11, 2002).

${ }^{22}$ Aside, The Common Law Origins of the Infield Fly Rule, 123 U. PA. L. REv. 1474 (1975). 
publish another law review article? Well, he broke that vow and, after saying goodbye forever to law reviews in 1936, said it all over again in an article he published in 1962 . $^{23}$ Law reviews will always be with us, and that is surely for the good. But you didn't need me to tell you that-you've already been around for 150 years. May you continue to enrich yourselves, and all of us in our broad, noble profession, for the next 150 .

${ }^{23}$ Fred Rodell, Goodbye to Law Reviews-Revisited, 48 VA. L. REV. 279 (1962). 
